\title{
AMELIORATIVE EFFECTS OF PHYTOANDROGEN AND ANTIOXIDANT ON HISTOARCHITECTURE OF PERMETHRIN INDUCED CHANGES IN GOAT TESTIS
}

\author{
SHIVANI BHARDWAJ, RAJNESH K SHARMA* \\ Reproductive Physiology Lab. Department of Zoology, Kurukshetra University, Kurukshetra 136119 \\ Email: rkskukz@gmail.com
}

Received: 21 Jul 2017 Revised and Accepted: 21 Sep 2017

\begin{abstract}
Objective: Protective effects of Tribulus terrestris (TT) and vitamin C were studied against permethrin induced changes in the histoarchitecture of goat testis.

Methods: Hydroalcoholic extract of the fruits of Tribulus terrestris was prepared by maceration method and the extractive value was calculated. Fresh stock solution of permethrin $(1 \mathrm{mg} / \mathrm{ml})$ in dimethyl sulphoxide and Tribulus terrestris $(1 \mathrm{mg} / \mathrm{ml})$ in distilled water were prepared. Testicular tissues were cultured in TCM-199 nutrition media at $39^{\circ} \mathrm{C}$ with $95 \%$ humidity and $5 \% \mathrm{CO}_{2}$ in the $\mathrm{CO}_{2}$ incubator. Cultured testicular tissue was grouped as control having only the nutritive media, experimental group I(EI) received two doses of permethrin $(100 \mu \mathrm{g} / \mathrm{ml}$ and $200 \mu \mathrm{g} / \mathrm{ml})$, experimental group II(EII) was administered doses of permethrin along with vitamin $\mathrm{C}(0.1 \mu \mathrm{M} / \mathrm{ml})$ and experimental group III(EIII) was supplemented with doses of permethrin along with Tribulus terrestris $(100 \mu \mathrm{g} / \mathrm{ml})$. All the groups were tested for $4 \mathrm{hr}$. and $8 \mathrm{hr}$. for histoarcitectural studies.
\end{abstract}

Results: Histological alterations were observed such as distorted shape of seminiferous tubules, decreased luminal and interstitial space, reduction in the population of spermatocytes, spermatozoa and spermatids in treated (E1) group as compared to control group. Maximum damage was detected at a higher dose of permethrin $(200 \mu \mathrm{g} / \mathrm{ml})$ for $8 \mathrm{~h}$ in contrast to lower doses (100 $4 \mathrm{~h}$ and $8 \mathrm{~h})$. Thus, it is concluded that permethrin has both dose and timedependent effects. Protective groups (E2 and E3) imparted ameliorative effects by reestablishing shape of seminiferous tubules, decreasing luminal and interstitial space, increased population of spermatocyte, spermatozoa, and spermatids as compared with treated groups (E1)

Conclusion: It has been reported that permethrin affects male fertility by inducing detrimental changes in the structure and function of seminiferous tubules. Both vitamin $\mathrm{C}$ and TT have the ability to mitigate the effect of pesticide. TT shows aphrodisiac activity against permethrin induced alterations in goat testis.

Keywords: Permethrin, Histoarchitecture of goat testis, Tribulus terrestris, Vitamin C

(C) 2017 The Authors. Published by Innovare Academic Sciences Pvt Ltd. This is an open access article under the CC BY license (http://creativecommons.org/licenses/by/4.0/) DOI: http://dx.doi.org/10.22159/ijpps.2017v9i11.21533

\section{INTRODUCTION}

In Ayurveda, medicinal plants have prominence value in curing several sexual disorders. Around $80 \%$ of the world population is still dependent on medicinal plants for health care and $20 \%$ of drugs in pharmaceutical firms are from plant sources [1]. In males, a number of medicinal plants are deployed for sexual stimulation or having properties for the treatment of oligospermia, sexual/ejaculatory dysfunction and several another malfunctioning. Some of the medicinal plants either have androgens or stimulate androgenic activity in males are known as phytoestrogens. These are basically secondary metabolites secreted by the plants. Androgens or male sex hormones are a class of steroid hormones produced in the male by testicular Leydig cells [2]. They are mainly responsible for sexual differentiation, development, maintenance of secondary male characteristics and for the initiation and maintenance of spermatogenesis [3]. Phytoandrogens possessing aphrodisiac properties, are Abelmoschus manihot, Asparagus racemosus, Spilanthes acmella, Tribulus terrestris [4] etc.

Tribulus terrestris (TT) (Zygophyllaceae), commonly known as 'Gokhru', is a medicinal herb, popular as Rasayana in Ayurvedic system of medicine in India [5]. It has been used since ancient times as an aphrodisiac as well as to treat urinary infections, inflammation, edema and other ailments [6]. TT can improve some aspects of male sexual behavior and enhance spermatogenesis in rats $[7,8]$. Increased androgen levels have also been reported after TT administration in nonhuman primates, rats and rabbits [9]. According to Chhatre et al. [10] dried fruits of TT have a dosedependent improvement in sexual behaviour. It was also reported that both TT [11] and vitamin C [12] can divulge protective effects against free radical generation.
The biological defense system of antioxidants comprises of enzymatic antioxidants such as catalase, SOD, glutathione peroxidase and non-enzymatic antioxidants are glutathione, carotenoids, a plant polyphenol, tocopherol and ascorbic acid. They have the ability to prevent the organism from the generation of reactive oxygen species (ROS) and thus, balance the oxidative stress of the body. The excess level of ROS leads to a state of oxidative stress that is detrimental to spermatogenesis and fertility [13]. Pesticides have the ability to disturb the oxidative stress level of the body. Ascorbic acid (vitamin C) is a puissant antioxidant that prevents free-radicals-induced DNA damage by pesticides [14]. Reports showed that vitamin $C$ at $1000 \mu$ mol/l concentration, have a protective effect against the testicular damage induced by atrazine at dose level $100 \mathrm{nmol} / \mathrm{ml}[15]$.

Pesticides are wide in use for exalting agriculture and pest control. Beside the beneficiary effects, they have adverse effects too, on different biological structures of non-targeted organisms. Pyrethroids, a class of insecticide seek more engrossment due to its nonpersistence and biodegradable properties. They interact reversibly with a wide range of ion channels, possibly via targeting sodium channels [16-18]. On the basis of cyano group pyrethroids are divided into two groups: type I and type II. Permethrin, type I, noncyano pyrethroid, is a common household insecticide. It has a wide spectrum of uses such as in pest management [19], medical treatment of scabies, both in agriculture and domestic practices.

They are quite specific to their target [20]. But several studies also have been reported for the detrimental effect of permethrin on a male reproductive system of non-targeted species. Zhange et al. [21] reported that oral administration of permethrin $(35$ or $70 \mathrm{mg} / \mathrm{kg} / \mathrm{d}$ ) for $6 \mathrm{w}^{*}$ in adult mice, resulted in a decrease in sperm count, sperm 
motility, plasma and testicular testosterone concentration. Some deteriorating effects of permethrin were also reported that affect the normal architecture of the mammalian testis [22]

Although experimental and clinical studies partially confirmed some effects of TT on libido and sperm production, thus there is still much debate regarding possible therapeutic applications. Therefore, the present work aimed to investigate ameliorative effects of TT and vitamin $\mathrm{C}$ against permethrin induced testicular toxicity in goat. Cultured tissues were processed for histological studies in dose and time-dependent manner.

\section{MATERIALS AND METHODS}

\section{Chemicals}

Permethrin(3-phenoxybenzyl-(1R,S)-cis,trans,3-(2,2-dichlorovinyl)2,2dimethylcyclopropanecarboxylate), having molecular formula: $\mathrm{C}_{21} \mathrm{H}_{20} \mathrm{Cl}_{2} \mathrm{O}_{3}$ and molar mass: $391.29 \mathrm{~g} / \mathrm{mol}$ with CAS no.52645-531, 98\% purity was procured from Nanz Medical Science Pharma Pvt. Ltd., Himachal Pradesh, India. A fresh stock solution of $1 \mathrm{mg} / \mathrm{ml}$ was prepared in dimethyl sulphoxide (DMSO, Sigma Chemical Co.). Further dilutions $(100 \mu \mathrm{g} / \mathrm{ml}$ and $200 \mu \mathrm{g} / \mathrm{ml})$ were made by dissolving it in tissue culture media of appropriate concentration.

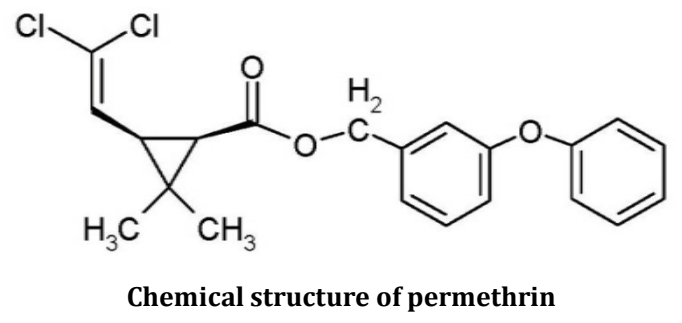

L-Ascorbic acid (CAS no:50-81-7, molecular formula: $\mathrm{C}_{6} \mathrm{H}_{8} \mathrm{O}_{6}$, molar mass: $176.13,99 \%$ purity) was obtained from Himedia Laboratories Pvt. Ltd., Mumbai, India. A fresh stock solution of 1 molar concentration was prepared. Further dilutions were made for final concentration $(0.1 \mu \mathrm{m} / \mathrm{ml})$.

\section{Collection and extraction of plant material}

The fruits of Tribulus terrestris (fig. 1) were collected from a roadside area of Kurukshetra University campus $\left(29^{\circ} 6^{\prime} \mathrm{N}, 76^{\circ}\right.$ $50^{\prime}$ E) and authenticated by Dr. B. D. Vashistha, Prof., Department of Botany, Kurukshetra University, Kurukshetra. A copy of herbarium (Voucher specimen no. Herbarium/BOT. KU/ZOO-1-2016) was deposited to Department of Botany for the record. The fruits of TT were shed dried, coarsely grinded and mixed with $70 \%$ alcohol in 1:9 ratio forming a mixture. The hydro-alcoholic extract was obtained by maceration of the mixture in large mouthed bottles under constant agitation in rotary flask shaker for $72 \mathrm{~h}$. The filtrate was collected and concentrated with a rotary evaporator (rotavapour R-300, Buchi) under reduced pressure at $40 \pm 2{ }^{\circ} \mathrm{C}$ and kept in a desiccator for drying. Fresh stock solution $(1 \mathrm{mg} / \mathrm{ml})$ was prepared and further used to make final concentration $(100 \mu \mathrm{g} / \mathrm{ml})$. The extractive yield was calculated and crude extract was stored at 4 ${ }^{\circ} \mathrm{C}$ future use.

\section{Sample collection}

The testes from mature goat (Capra hircus) was obtained from slaughterhouses around Kurukshetra (29 $\left.{ }^{\circ} 6^{\prime} \mathrm{N}, 76^{\circ} 50^{\prime} \mathrm{E}\right)$ and was brought to the lab. at $4{ }^{\circ} \mathrm{C}$ in normal saline.

\section{Testicular tissue culture}

After decapsulation, a testis was cut into smaller pieces approximately $1 \mathrm{~mm}^{3}$ in size. Testicular tissues were washed thrice with TCM-199 and placed on the nucleopore filter and floated on medium. The medium constitutes TCM-199 and antibiotics (200units having a concentration of penicillin $100 \mathrm{IU} / \mathrm{ml}$ and streptomycin $100 \mathrm{IU} / \mathrm{ml}$ ) at $39^{\circ} \mathrm{C}$ with $95 \%$ humidity and $5 \% \mathrm{CO}_{2}$ in the $\mathrm{CO}_{2}$ incubator as per experimental layout [15].

\section{Experimental design}

The testicular tissue was divided into four groups. Group-I served as control. Rests were the experimental group's i.e. E1, E2, E3. E1 (Treated group) was tested for two different doses $(100 \mu \mathrm{g} / \mathrm{ml}$ and $200 \mu \mathrm{g} / \mathrm{ml}$ ) of permethrin for a different time duration $(4 \mathrm{~h}$ and $8 \mathrm{~h})$. Groups E2 and E3 (protective groups) were administered with different doses of permethrin along with vitamin $\mathrm{C}(0.1 \mu \mathrm{M} / \mathrm{ml})$ and TT $(100 \mu \mathrm{g} / \mathrm{ml})$ respectively. All the groups further proceeded for histopathological studies.

\section{Histomorphological studies [Pearse, 1968]}

After the treatment, testicular tissue from both control and experimental groups were processed for histomorphological studies using the standard techniques given by Pearse (1968) with slight modifications. Cultured tissues were fixed in Bouin's fixative, followed by dehydration through series of alcoholic grades and clearing with two successive changes with xylene. Tissues were embedded in paraffin wax. The tissues were sectioned serially at $5 \mu \mathrm{m}$ thickness with rotatory microtome followed by stretching and dewaxing by xylene for $15 \mathrm{~min}$. The slides were passed through the different grades of alcohol and stained with hematoxylin and eosin standard staining technique. Slides were visualized under Olympus CX41 having Magnus digital adaptor. Photomicrographs were captured using Olympus digital camera fitted to microscope at 400X.

\section{RESULTS}

\section{Extractive value}

The extractive value of TT was found to be $6.9 \%(\mathrm{w} / \mathrm{w})$.

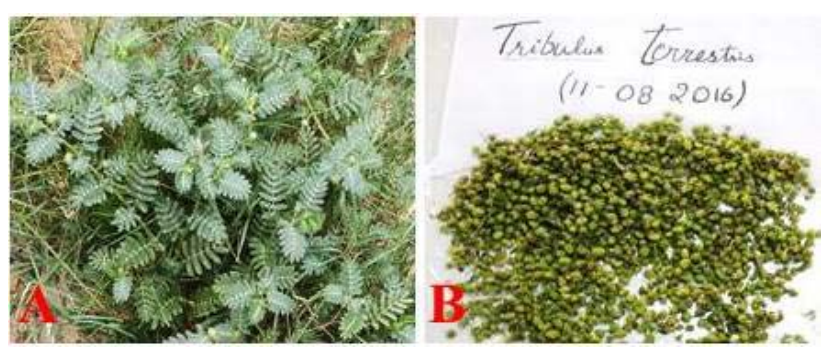

Fig. 1: Showing (A) plant of Tribulus terrestris (B) fruit of Tribulus terrestris

\section{Effects of permethrin on histoarchitecture of goat testis}

The present study revealed that permethrin affects the normal architecture of goat testicular tissue. Deteriorating effects of permethrin were observed in E1 experimental group as compared to the control of same time duration. Effects of two different doses of permethrin $(100 \mu \mathrm{g} / \mathrm{ml}$ and $200 \mu \mathrm{g} / \mathrm{ml})$ were studied. $100 \mu \mathrm{g} / \mathrm{ml}$ dose of permethrin showed that shape of seminiferous tubule was intact, luminal space was a little bit widen, little destruction in a basal membrane having a spermatogonial cell, vacuolization in the interstitial space was observed, mature sperm were relatively low as compared to control group. $200 \mu \mathrm{g} / \mathrm{ml}$ dose showed hyalinization and distortion to the shape of seminiferous tubules, scarcity of mature germ cells, vacuolization in the lumen, interstitium was scanty with few Leydig cells, reduced luminal spermatozoa when compared with $100 \mu \mathrm{g} / \mathrm{ml}$ and control (fig. 2B, D). Microphotographs depicted dose-dependent effects of permethrin as dose increased more detrimental effects were observed. Another, the most decisive parameter was a time of treatment of permethrin in inducing damage. $100 \mu \mathrm{g} / \mathrm{ml}$ dose for $4 \mathrm{~h}$ of culture duration show slight changes in shape and structure of seminiferous tubules as compared to control but $100 \mu \mathrm{g} / \mathrm{ml}$ dose for $8 \mathrm{~h}$ showed abrasive effects in the shape of seminiferous tubules. More vacuolization and decreased population of spermatogonia, spermatozoa, as well as spermatids, were observed (fig. 2C). A similar trend was detected with dose $200 \mu \mathrm{g} / \mathrm{ml} \mathrm{4h}$ (fig. 2B) and $8 \mathrm{~h}$ (fig. 2D). The maximum devastation was noted with maximum dose and time duration i. e. at $200 \mu \mathrm{g} / \mathrm{ml}$ 8h (fig. 2D). 


\section{Effect of TT and vitamin $C$ on permethrin induced changes}

Experimental group, E2 was administered with two different dose of permethrin along with vitamin $\mathrm{C}$ for two different time durations (fig. $2 \mathrm{E}, \mathrm{F}, \mathrm{G}, \mathrm{H}$ ). $100 \mu \mathrm{g} / \mathrm{ml} 4 \mathrm{~h}$ along with vitamin $\mathrm{C}$ had significant restoring consequences (fig. 2E). The shape of seminiferous tubules reestablished upto a remarkable extent, gross increase in sperms and spermatogonia were observed. Luminal diameter found to be reduced as compared to E1 treated groups (fig. 2B,C,D). Mitigating effects were more prominent at maximum dose, $200 \mu \mathrm{g} / \mathrm{ml} 8 \mathrm{~h}$ with vitamin C (fig. $2 \mathrm{H}$ ). Another group, E3 was supplemented with permethrin and hydroalcoholic extract of TT. It was discerned that seminiferous tubules were found intact in all the TT augmented groups (fig. $2 \mathrm{I}, \mathrm{J}, \mathrm{K}, \mathrm{L}$ ). Luminal diameter showed decreasing trend in contrast with treated groups. Hyalinization and pyknosis were not observed. Although at higher doses, $(100 \mu \mathrm{g} / \mathrm{ml} 8 \mathrm{~h}$ (fig. $2 \mathrm{~K})$ and $200 \mu \mathrm{g} / \mathrm{ml}$ 8h (fig. $2 \mathrm{~L}$ ) vacuolization was noticed at some place in basal membrane of tubules (fig. 2K,J,L). Abundance of sperm in E3 showed that TT has an aphrodisiac property which helps in the reestablishment of the structure of seminiferous tubule.

\section{DISCUSSION}

Pesticide lashed food resources are responsible for several sexual implications in human and wildlife. It has aroused a great concern for the toxic status of these pesticides, among biologist, toxicologist and health scientists. The present study has revealed the protective effect of TT and vitamin C on deteriorating effects of permethrin on goat testis. Earlier studies have demonstrated that permethrin, cause nerve impulse train of short duration [24] thus affecting the normal functioning of the testis. The results of present study revealed that after treatment with different doses $(100 \mu \mathrm{g} / \mathrm{ml}$ and $200 \mu \mathrm{g} / \mathrm{ml}$ ) of permethrin for different time durations ( $4 \mathrm{~h}$ and $8 \mathrm{~h}$ ) showed deleterious histological alterations in the goat testis. Treated groups revealed shrinkage of the seminiferous tubules, pyknosis in some basal spermatogonial cells, and reduction in the population of mature sperm thus widening of luminal diameter. Both Perry et al. [25] and Yuan et al. [26] have observed that increased exposure to permethrin and its metabolites result in lower sperm concentrations in mammals. Present findings are in consonance with, Issam and coworkers [27] who have described that permethrin treated groups have decreased the population of spermatocytes, spermatids and spermatozoa.

According to Omotoso et al. [22] animals fed on permethrincontaining feeds exhibited some degree of damage in the general histology of their seminiferous tubules. Permethrin could directly reduce sperm motility in vitro [26]. Rosita and coworkers [12] substantiated that the permethrin leads to dose and time-dependent DNA damages and mutagenic alterations in rats. The present study has revealed that permethrin had dose and time-dependent effects. It was observed that experimental group having highest exposure duration showed maximum loss of cells in testis. Thus, It is plausible to speculate from our results that some parameters such as dose as well as exposure duration, are potent determinants for the cell disturbances and functioning of the testis.
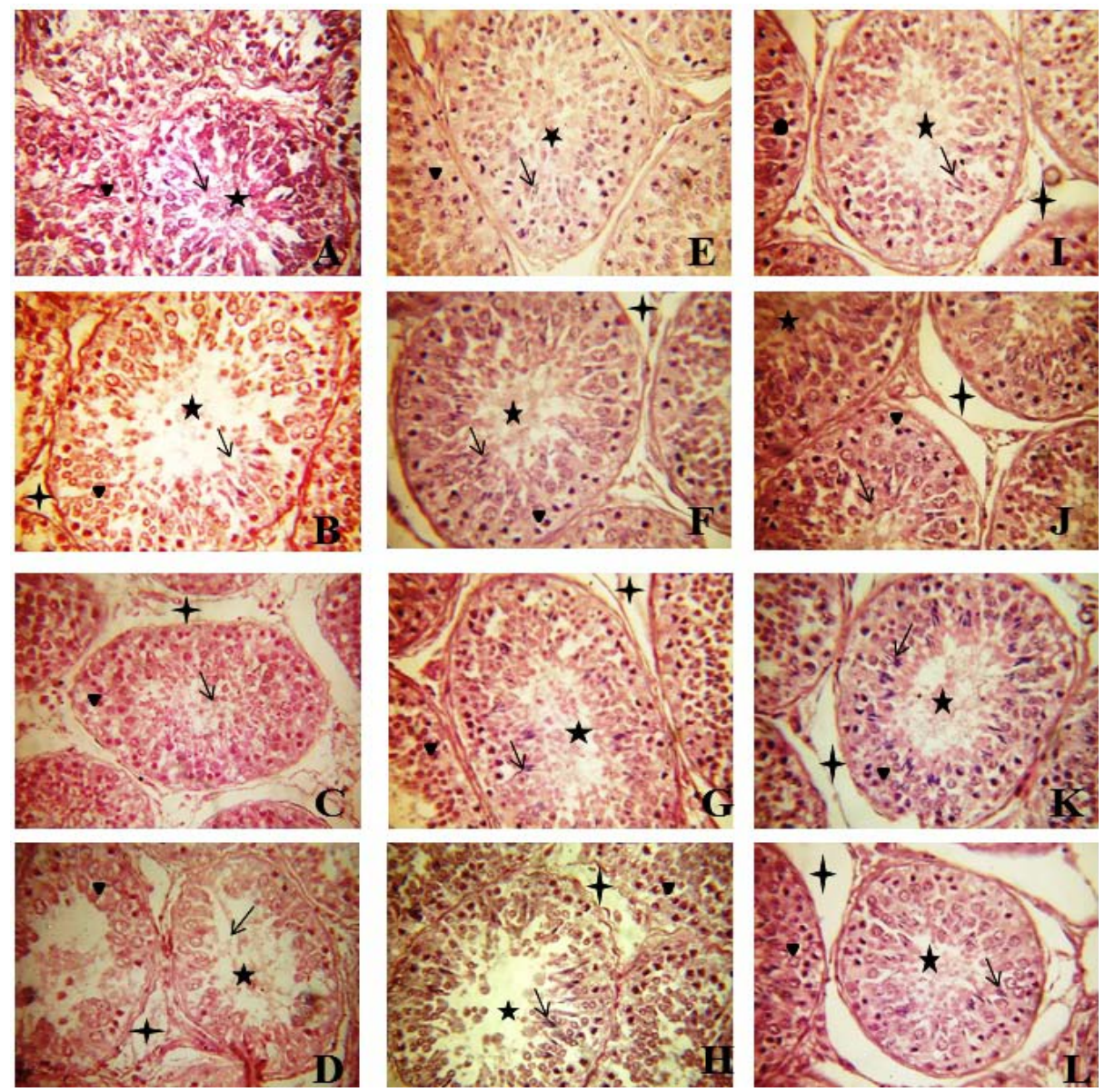

Fig. 2: Histoarchitectural studies of testis sections stained with $H$ and $E$ (400x). (A) the healthy control group (arrows: populated lumen with mature sperm, arrowhead: basal membrane rich in spermatogonia). (E2) Treated group (B, C, D): $B$ [4h] represents vacuolization and pyknosis in the basal membrane, star: widen luminal space; $C$ and $D$ [8h] showing hyalization, asterisk: widen interstitial space, arrow: a decline in a number of sperms. Vitamin C supplemented group (E3) [E, F (4h) and G, H (8h)] represented arrow: increased sperm population in lumen; asterisk: reduced interstitial space. E4 group administered with Tribulus terrestris[I, J (4h) and K, L (8h)] showing reestablished shape of seminiferous tubule, asterisk: depletion in interstitial space, star: lumen populated with mature sperms(arrow), arrowhead: abundant number of spermatogonia in basal membrane 
Studies showed that TT extract contains protodioscin (PTN), a steroidal saponin which was known for its aphrodisiac property. PTN is also found to increase the levels of testosterone, leutinizing hormone [28], dehydroepiandrosterone [29], dihydrotestosterone and dehydroepiandrosterone sulphate [30]. The present study also demonstrated the mitigating effect of TT. It was observed that E3 experimental group have more spermatozoa and spermatogonia. The shape of seminiferous tubules was also seen to be significantly restored. It can be concluded that TT has potential aphrodisiac activity on permethrin induced toxicity in goat testis. The present finding are contrary to the observation of Neychev and Mitev [31] who have reported that TT unable to increase the levels of androgenic hormones in young humans. Whereas the present observations are in agreement with the effected works by, Kumari and Singh [32] demonstrated that the fruit extract of TT $(200 \mathrm{mg} / \mathrm{kg}$ BW/day) has the ability in restoring the metronidazole-induced spermatogenic inhibition and reduction in epididymal sperm count. TT administration to cadmium treated rats also showed remarkable recovery against testicular tissue peroxidation in rat [11].

Vitamin C may effectively minimize free radicals in biological systems and considered to be the first line of defence [33] against an early stage of free radical attack. Present work was in agreement that vitamin C, was potent for counteracting permethrin induced alteration. As vitamin C supplemented group showed less abnormality such as decreased luminal space, increased the population of spermatozoa and spermatogonia with respect to permethrin-treated groups. The protective effect of vitamin C was observed to be both dose and time-dependent. In conformity with the earlier studies of Gabbianelli and coworkers [12] wherein, protective effect on the erythrocytes against the oxidative injury caused by permethrin has been documented. It was stated that the capacity of vitamins $\mathrm{E}$ and $\mathrm{C}$, is the time of supplementation. According to Meydani et al. [34] long-term supplementation of diet with $\alpha$-tocopherol has little effect on the prevalence of disease or lifespan of mice. Assayed et al. [35] observed that natural agents such as garlic extract or vitamin $\mathrm{C}$ have the ability to reduce teratogenic parameters in cypermethrin triggered free radical injury in the embryos of exposed rats. Both TT and vitamin C have potential to ameliorate deleterious effects of permethrin.

\section{CONCLUSION}

Present study showed that permethrin is a potent insecticide which adversely affects the shape and structure of seminiferous tubules. The number of spermatogonia, spermatozoa, and spermatid was also affected. More destructive outcomes were noticed within $200 \mu \mathrm{g} / \mathrm{ml} 8 \mathrm{~h}$ dose of permethrin. In protective groups, significant restoring effects were observed regarding with shape of seminiferous tubules and number of germ cells. Thus the concomitant administration of natural antioxidants such vitamin C and TT are a persuasive dietary supplement that can reverse the toxic effect of permethrin.

\section{ACKNOWLEDGEMENT}

The authors are thankful to the Kurukshetra University, Kurukshetra for the financial support granted as University Research Scholarship to Ms. Shivani and grateful to Department of Zoology for providing laboratory facilities throughout the study.

\section{AUTHORS CONTRIBUTION}

(1) Shivani performed the experiment, develop the theoretical framework and drafted the manuscript (2) Prof. R. K. Sharma makes substantial contributions in conception, designing and supervison of the present work.

\section{CONFLICT OF INTERESTS}

Authors have none to declare

\section{REFERENCES}

1. Shankar D, Majumdar B. Beyond the biodiversity convention: the challenges facing the biocultural heritage of India's medicinal plants. FAO 1997;11:87-99.

2. Roy $\mathrm{P}$, Alevizaki M, Huhtaniemi I. In vitro bioassays for androgens and their diagnostic applications. Hum Reprod Update 2007;14:73-82.
3. McEwan IJ. Molecular mechanisms of androgen receptormediated gene regulation: structure-function analysis of the AF-1 domain. Endocr Relat Cancer 2004;11:281-93.

4. Singh S, Nair V, Gupta YK. Evaluation of the aphrodisiac activity of Tribulus terrestris Linn. in sexually sluggish male albino rats. J Pharmacol Pharmacother 2012;3:43.

5. Nadkarni KM. Indian Materia Medica. Popular Prakashan (Mumbai); 1927. p. 1230

6. Adaikan PG, Gauthaman K, Prasad RN. History of herbal medicines with an insight on the pharmacological properties of Tribulus terrestris. Aging Male 2001;4:163-9.

7. Gauthaman K, Adaikan PG, Prasad RN. Aphrodisiac properties of Tribulus terrestris extract (Protodioscin) in normal and castrated rats. Life Sci 2002;71:1385-96.

8. Gauthaman K, Ganesan AP, Prasad RN. Sexual effects of puncturevine (Tribulus terrestris) extract (protodioscin): an evaluation using a rat model. J Altern Complementary Med 2003;9:257-65.

9. Gauthaman K, Ganesan AP. The hormonal effects of Tribulus terrestris and its role in the management of male erectile dysfunction-an evaluation using primates, rabbit and rat. Phytomedicine 2008;15:44-54.

10. Chhatre S, Nesari T, Somani G, Kanchan D, Sathaye S. Phytopharmacological overview of Tribulus terrestris. Pharmacogn Rev 2014;8:45.

11. Rajendar B, Bharavi K, Rao GS, Kishore PV, Kumar PR, Kumar CS, et al. Protective effect of an aphrodisiac herb Tribulus terrestris Linn on cadmium-induced testicular damage. Indian J Pharmacol 2011;43:568.

12. Gabbianelli R, Nasuti C, Falcioni G, Cantalamessa F. Lymphocyte DNA damage in rats exposed to pyrethroids: effect of supplementation with vitamins $\mathrm{E}$ and $\mathrm{C}$. Toxicology 2004;203:17-26.

13. Agarwal A, Saleh RA, Bedaiwy MA. Role of reactive oxygen species in the pathophysiology of human reproduction. Fertil Steril 2003;79:829-43.

14. Devasagayam TP, Tilak JC, Boloor KK, Sane KS, Ghaskadbi SS, Lele RD. Free radicals and antioxidants in human health: current status and future prospects. J Assoc Physicians India 2004;52:794-804.

15. Sharma RK, Fulia A, Chauhan PK. Antioxidant (Ascorbic acid): an approach to ameliorate the atrazine-induced testicular toxicity. J Med Sci 2010;10:169-75.

16. Davies TG, Field LM, Usherwood PN, Williamson MS. DDT, pyrethrins, pyrethroids and insect sodium channels. IUBMB Life 2007;59:151-62.

17. Narahashi $\mathrm{T}$, Zhao $\mathrm{X}$, Ikeda $\mathrm{T}$, Nagata $\mathrm{K}$, Yeh JZ. Differential actions of insecticides on target sites: basis for selective toxicity. "Hum Exp Toxicol 2007;26:361-6.

18. Peterson RT, Nass R, Boyd WA, Freedman JH, Dong K, Narahashi T. Use of non-mammalian alternative models for neurotoxicological study. Neurotoxicology 2008;29:546-55.

19. Jamjoom GA, Mahfouz AA, Badawi IA, Omar MS, Al-Zoghaibi OS, Al-Amari OM, et al. Acceptability and usage of permethrinimpregnated mosquito bed nets in rural southwestern Saudi Arabia. Trop Geogr Med 1993;46:355-7.

20. Wolansky MJ, Harrill JA. Neurobehavioral toxicology of pyrethroid insecticides in adult animals: a critical review. Neurotoxicol Teratol 2008;30:55-78.

21. Zhang SY, Ito Y, Yamanoshita O, Yanagiba Y, Kobayashi M, Taya $\mathrm{K}$, et al. Permethrin may disrupt testosterone biosynthesis via mitochondrial membrane damage of Leydig cells in the adult male mouse. Endocrinology 2007;148:3941-9.

22. Omotoso GO, Onanuga IO, Ibrahim R. Histological effects of permethrin insecticide on the testis of adult wistar rats. Biomed Biotechnol Res J 2014;6:125-9.

23. Pearse AGE. Histochemistry. 3rd edition. Vol. 1. Little, Brown and Co. Boston 1968;1:1-759.

24. Perger G, Szadkowski D. Toxicology of pyrethroids and their relevance to human health. Ann Agric Environ Med 1994;1:11-7.

25. Perry MJ, Venners SA, Barr DB, Xu X. Environmental pyrethroid and organophosphorus insecticide exposures and sperm concentration. Reprod Toxicol 2007;23:113-8. 
26. Yuan C, Wang C, Gao SQ, Kong TT, Chen L, Li XF, et al. Effects of permethrin, cypermethrin and 3-phenoxy benzoic acid on rat sperm motility in vitro evaluated with computer-assisted sperm analysis. Toxicol In Vitro 2010;24:382-6.

27. Issam C, Zohra H, Monia Z, Hassen BC. Effects of dermal subchronic exposure of pubescent male rats to permethrin (PRMT) on the histological structures of the genital tract, testosterone and lipoperoxidation. Exp Toxicol Pathol 2011;63:393-400.

28. Koumanov F, Bozadjieva E, Andreeva M, Platonva E, Ankov V. Free serum testosterone level in male rats treated with tribulus alatus extracts. Clin Trial Tribestan Exp Med 1982;4:211-5.

29. Adimoelja A, Adaikan PG. Protodioscin from herbal plant Tribulus terrestris L improves the male sexual functions, probably via DHEA. Int J Impotence Res 1997;9(Supp 1):S1-70.

30. Gauthaman K, Adaikan PG, Prasad RN, Goh VH, Ng SC. Changes in hormonal parameters secondary to intravenous administration of Tribulus terrestris extract in primates. Int J Impot Res 2000;12:6.
31. Neychev VK, Mitev VI. The aphrodisiac herb Tribulus terrestris does not influence the androgen production in young men. J Ethnopharmacol 2005;101:319-2.

32. Kumari M, Singh P. Tribulus terrestris ameliorates metronidazole-induced spermatogenic inhibition and testicular oxidative stress in the laboratory mouse. Indian J Pharmacol 2015;47:304.

33. Altuntas I, Delibas N, Demirci M, Kilinc I, Tamer N. The effects of methidathion on lipid peroxidation and some liver enzymes: the role of vitamins E and C. Arch Toxicol 2002;76:470-3.

34. Meydani M, Lipman RD, Han SN, Wu D, Beharka A, Martin KR, et al. The effect of long-term dietary supplementation with antioxidants. Ann N Y Acad Sci 1998;854:352-60.

35. Assayed ME, Khalaf AA, Salem HA. Protective effects of garlic extract and vitamin $\mathrm{C}$ against in vivo cypermethrin-induced teratogenic effects in rat offspring. Food Chem Toxicol 2010;48:3153-8. 